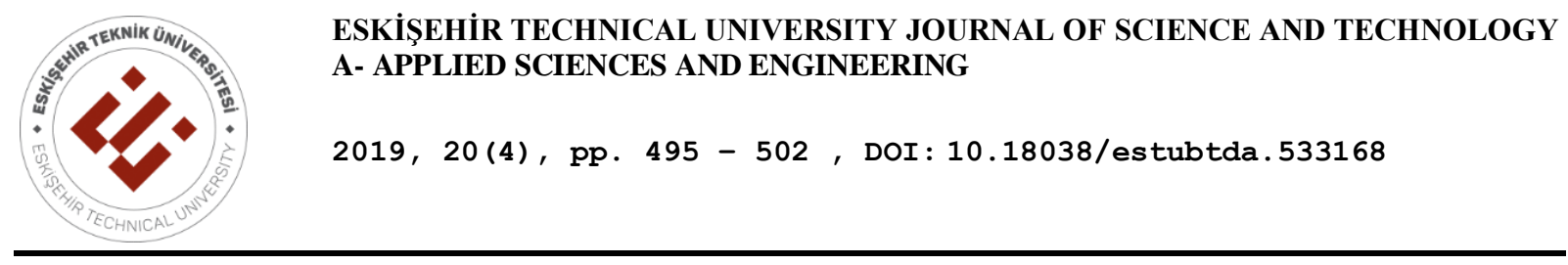

\title{
MICROBIOLOGICAL, CHEMICAL COMPOSITIONS AND ANTIOXIDANT CAPACITY OF TARHANA CHIPS FERMENTED WITH KEFIR
}

\author{
Didem ŞAHINGIL ${ }^{*}$ \\ Department of Food Engineering, Faculty of Engineering, İnönü University, Malatya, Turkey
}

\begin{abstract}
In this study, the tarhana samples which fermented with kefir show higher antioxidant activity than tarhana samples which are fermented with yogurt (without kefir grains). The control tarhana chips (fermented with yogurt) samples $(0,47 \pm 0,51$ $\mu \mathrm{mol} / \mathrm{g}$ TE) have significantly $(P<0.05)$ lower antioxidant capacity $(D P P H$ radical scavenging activity) than the fermented with kefir $(0,67 \pm 0,02 \mu \mathrm{mol} / \mathrm{g}$ TE) samples. The ABTS values $(0,83 \pm 0,28 \mu \mathrm{mol} / \mathrm{TE}$ gr and $0,71 \pm 0,32 \mu \mathrm{mol} / \mathrm{TE} \mathrm{gr})$ of extracts are significantly different in YT sample and KT samples fermented with kefir. The difference in antioxidant activities of traditional tarhana chips and tarhana with kefir grains are statistically significant $(P<0.05)$. The analysis of total coliform group bacteria, total aerobic mesophilic bacteria, total Lactobacillus spp. and yeast-mould counts were conducted in samples. None of the samples contained coliform group bacteria. At the end of fermentation, count of Lactobacillus spp. and total aerobic mesophilic bacteria for traditional tarhana chips and fermented chips with kefir determined 8,47-8,94 log cfu/g and 7.43-7.95 log cfu/g, respectively. Yeast counts in the samples of chips fermented with kefir found 6,89 log cfu/g. As a result, the use of kefir instead of yogurt in tarhana chips production is highly recommended as a tarhana type which has the potential to be a highly functional product with a high nutritional value due to its significant increase in antioxidant properties and its contribution to protein content.
\end{abstract}

Keywords: Tarhana chips, Kefir, Antioxidant activity

\section{INTRODUCTION}

Fermented food play an important role in the diets of many people in Asia, the Near East and parts of Africa. Cereal products are important sources for the daily protein, carbohydrate, vitamin, mineral and dietary fiber needs. However, the fermentation of these products has resulted in significant increases in both the quality of food and the sensory properties [1]. Tarhana, a fermented nutrient commonly consumed in the Middle East, is prepared by mixing wheat flour, yogurt, yeast and spices and drying them for several days fermentation and drying after fermentation [2]. It is is fermented at $25-30^{\circ} \mathrm{C}$ during 1-7 days and then dried under traditional conditions. Tarhana is a good source of protein and vitamins and has been largely used by children and older people in the form of a thick soup. [3,4] TS 2282 standard specifies tarhana related characteristics. In this standard tarhana means "tarhana", "wheat flour, crumbs, semolina or mixture thereof and yoghurt, pepper, salt, onion, tomato and flavor, fragrance, health harmless vegetable materials are mixed and kneaded and fermented, is a nutrient obtained by milling and screening. [2,6-30]. In winter days, tarhana is usually consumed as soup [5]; however, on different types of ingots Tarhana called Tarhana chips are dried in a thin layer, particularly as the soup is consumed instead of tortilla chips in Kahramanmaras in Turkey[6].

Tarhana production methods differ depending on the region [7] but cereals and yoghurt are always the major components of this product [8]. Hence, Tarhana chips can be recognized as a dairy (yoghurt)based fermented food. In the production of Maraş tarhana with 'wheat dövme' (special product of wheat) is kneaded, as well as adjunct ingredients such as thyme and black cumin (Nigella sativa) which contribute to the taste and nutritional value of the product are added. In production method; the wheat dövme is cooked with boiled water and added so that the salt content does not exceed $1 \%$ $(\mathrm{w} / \mathrm{w})$. After the mixture has cooled down, yoghurt, thyme and black cumin are added and the resulting mixture is allowed to fermentation. Then, the mixture is lay out on wicker type shape called

*Corresponding Author: didem.sahingil@inonu.edu.tr

Received: 27.02.2019 Published: 30.12.2019 
"çı̆̆" and the water of the tarhana is removed to provide fermentation and drying of the tarhana. After the drying process, the tarhana is taken from the çı̆ and broken in appropriate size, packed and stored $[6,9-10]$.

Another traditional food is kefir; is a fermented dairy product in which kefir grains are used. Kefir grains are small irregularly shaped, yellowish-white, hard granules which resemble miniature cauliflower blossoms. Kefir is produced by adding kefir grain into cow's or goat's milk under mesophilic conditions and it was produced an acidic alcoholic beverage at the end of fermentation process [11].

As a result of fermentation of both lactic acid bacteria and yeasts, kefir produces lactic acid, acetic acid, small amounts of carbon dioxide $\left(\mathrm{CO}_{2}\right)$, ethyl alcohol and aromatic compounds that provide different organoleptic properties. Kefir; It is also considered as a natural probiotic including the metabolites of these microorganisms along with the bacteria and yeasts found in the kefir. Kefir species include lactic acid bacteria, Leuconostocs, acetic acid bacteria, Streptococci and yeasts and this complex microflora in a symbiotic relationship and are responsible for alcoholic and lactic acid fermentation, respectively [13]. Kefir is widely known as an excellent source of probiotics with potential health benefits. It was reported that some types of milk (e.g., cow's, ewe's, goat's milk) have been used in the manufacture of kefir [14,15-16]. However, researches are scarcely on use of small ruminant milk in production. We aimed to produce Tarhana chip with addition of kefir to enhance its functional properties and, to the authors' knowledge no study was conducted on Tarhana chips containing kefir. In this study, the effect of replacement yogurt in tarhana chips by adding kefir on fermentation and some properties (antioxidant properties, colour, microbial and chemical composition) was investigated.

\section{MATERIALS AND METHODS}

\subsection{Manufacture of Tarhana chips}

Tarhana prepared with two different formulations: (1) Traditional tarhana cips with cereal (special wheat product) and yogurt (2) Tarhana chips with cereal (special wheat product) and kefir (Figure 1a).

In the preparation of tarhana chips, whole wheat flour (Turkish Food Codex Wheat Flour Codex No: 2013/9) full fat (> 3.8\%) yogurt (Turkish Food Codex Fermented Dairy Products Codex, No: 2009/25 appropriate and salt (Turkish Food Codex Spice Codex No: 2013/12). Crude protein of yoghurt and kefir used in the production of tarhana chips were $4.2 \%$ and $3.8 \%$ respectively.

The raw cows' milk used for the kefir production. After standardisation of fat ( $\min 2 \mathrm{~g} / 100 \mathrm{~mL}$ ), the kefir milk was heated at $90{ }^{\circ} \mathrm{C}$ for $5 \mathrm{~min}$, then cooled to $23{ }^{\circ} \mathrm{C}$ for the production. Milk used to produce traditional kefir $(\mathrm{K})$ was inoculated with $3 \%(\mathrm{w} / \mathrm{v})$ kefir grains. Incubation was carried out at $23 \pm 0.5{ }^{\circ} \mathrm{C}$ in a thermostatically incubator (Sartorius, Sedim Biotech certomot ${ }^{\circledR}$ IS, Goettingen, Germany) until pH 4,6 (Mettler Toledo Seven Compact pH meter, Switzerland) (which takes about 22 h). After fermantation, the grains were separated from kefir beverage by filtration. After fermentation, kefir was stored for one day at $4{ }^{\circ} \mathrm{C}$ in a refrigerator. Kefir and yogurt using tarhana chips production dry matter was standardized $15 \%$.

According to the traditional method of making tarhana chips according to the procedure to be used in the construction of wheat tarhana; white wheat, the grain shape should be close to the round and also clean and sifted. Special tarhana wheat was obtained by beating, milling and forging, milling and sorting. In the evening before the specified day, the forged was washed by wetting about $5 \mathrm{~kg}$ of stainless steel containers. The product was cooled to $22-25{ }^{\circ} \mathrm{C}$ when cooked. Cooked dövme was mixed with a $2 \mathrm{~kg}$ yogurt $/ 2 \mathrm{~kg}$ kefir and $0.8 \%$ salt for each $1 \mathrm{~kg}$ of wheat dövme in stainless steel 
mixers. Kefir or yoghurt, cooled weat dövme and salt mixture were into stainless steel and subjected to fermentation for 24 hours. At the end of the fermentation, it was lay out on wicker type called "çı̆̆" spread to dry. Thus, tarhana chips are drained and drying in the sun. Dryed Tahana chips are packed in small pieces and packed.

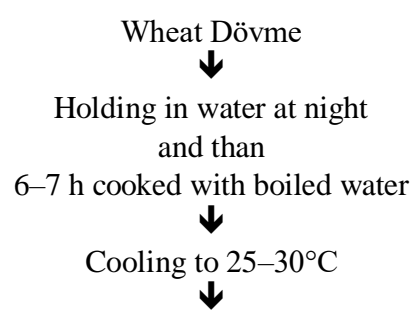

Addition of adjunct ingredients and than fermentation

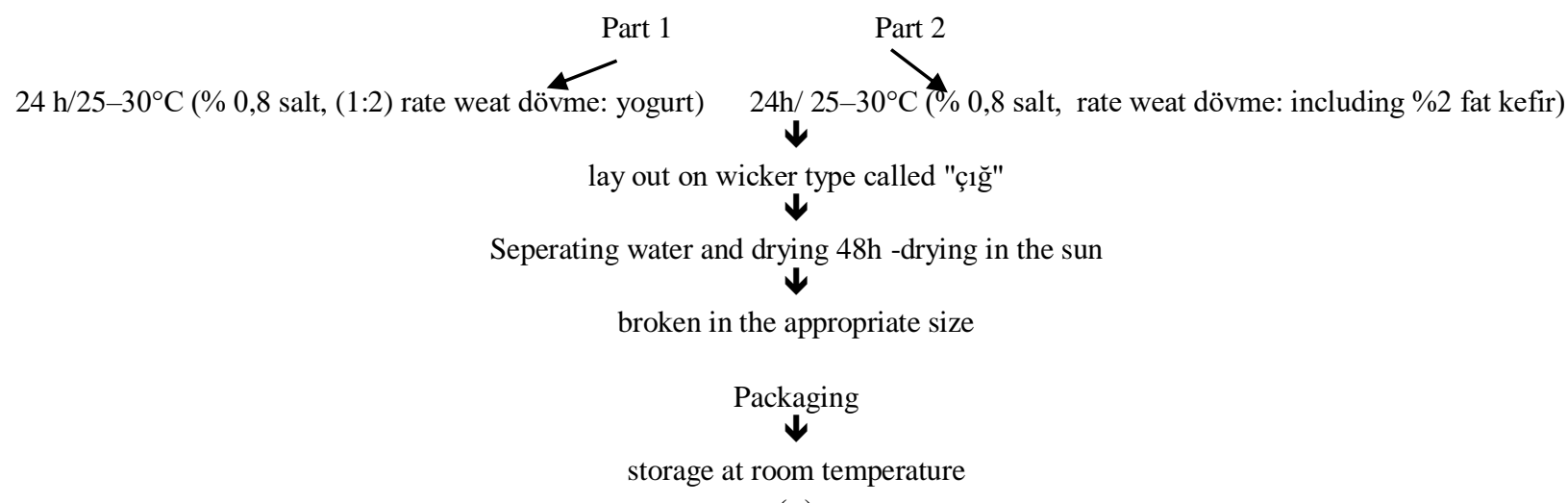

(a)

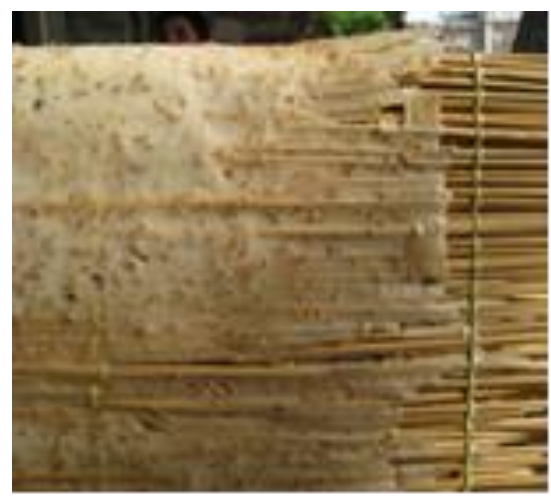

(b)

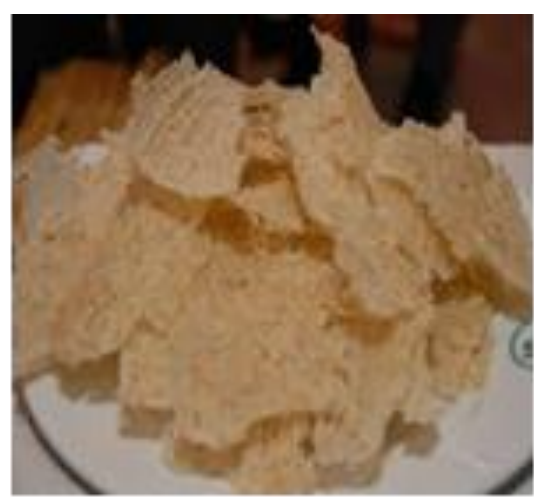

(c)

Figure 1. (a) Manufacture of Tarhana chips which fermented with kefir; (b) Tarhana chips lay out on wicker type called "çı̆̆" (c) Tarhana chips

\section{Chemical analysis of Tarhana chips}

All samples were analyzed in duplicate for total solids, ash, content of tarhana chips were determined according to [17] procedures. Total nitrogen content of all samples by the micro-Kjeldahl method [18]. 


\subsection{Antioxidant properties of Tarhana chips}

\subsubsection{DPPH radical scavenging activity of samples}

The analytical method was performed with the use of modified methods proposed by [19]. DPPH (2,2-diphenyl-1- picrylhydrazyl) solution was prepared by dissolving $24 \mathrm{mg}$ of DPPH in $100 \mathrm{~mL}$ methanol and kept at $-20^{\circ} \mathrm{C}$ until analysis. The working solution was obtained by diluting of the stock solution of the DPPH reagent (methanol, absorbance of $0,70 \pm 0,02$ at $515 \mathrm{~nm}$ ). $1 \mathrm{~g}$ of tarhana samples was mixed with $10 \mathrm{~mL}$ of aqueous methanol. The mixture was sonicated bath for $10 \mathrm{~min}$ in an ultrasonic bath (Bandelin Sonorex, U230 RK 514H, Berlin, Germany). After the centrifugation of the mixture (Hettich, Universal R320, Hettich Co., Germany) at $13500 \times g$ at $4^{\circ} \mathrm{C}$ for $10 \mathrm{~min}$, supernatants were seperated into vials. Tarhana extracts $(100 \mu \mathrm{L})$ were allowed to react with the working solution $(2900 \mu \mathrm{L}$ ) in the dark at room for $60 \mathrm{~min}$., absorbance was measured at $515 \mathrm{~nm}$ (using UV-1800 spectorophotometer, Shımadzu, Japan) against the reference sample (99,5\% pure methanol, v/v). The standard calibration curve was linear between 0 and $800 \mu \mathrm{mol}$ Trolox equivalent/g. The tests were performed in duplicates and the antioxidant capacity were expressed as micromoles of trolox per $\mathrm{g}$ of sample by means of a curve for Trolox (5-500ppm).

\subsubsection{ABTS radical cation scavenging activity of samples}

This assay was based on the ability of different substances to ABTS (2,2'-azino-bis; ethylbenzthiazoline-6-sulfonic acid) radical cation. The ABTS stock solution was prepared by mixing $7 \mathrm{~m} M$ ABTS with $2,45 \mathrm{~m} M$ potassium persulfate (v/v: $1: 1)$ and the solution was left in the dark at room temperature until 4-16 h. this solution was diluted with ethanol to reach an absorbance of 0,700 $\pm 0,05$ at $734 \mathrm{~nm}$ for measurement. The assay was conducted on $100 \mu \mathrm{L}$ of the tarhana chips sample extract and $2400 \mu \mathrm{L}$ of ABTS•+ solution was mixed for $30 \mathrm{sec}$; the absorbance was measured immediately at $734 \mathrm{~nm}$ after $10 \mathrm{~min}$, against ethanol with spectrophotometer (UV-1800, Shimadzu, Japan). The results were calculated as micromoles of trolox per $g$ of sample by means of a curve for Trolox (1-100 ppm) [19].

\subsection{Colour measurement of Tarhana chips}

A Hunter calorimeter (Konica Minolta, Chroma Metter CR-5, Japan) was used for color measurement and were calibrated using white calibration plate immediately before the study. The lightness $\left(\mathrm{L}^{*}\right.$ value), redness ( $a^{*}$ value) and yellowness $\left(b^{*}\right.$ value) of Tarhana chips were determined into a petri dish. Eight readings were taken per sample and they were averaged.

\subsection{Microbiological analysis of Tarhana chips}

Tarhana chips samples were analyzed for total aerobic mesophilic bacteria (TAMB), Lactobacillus spp., total coliform group bacteria and yeast-mould as described by [20].

\subsection{Statistical Analyses}

The data obtained from two trials were analysed statistically using the analysis of variance (ANOVA) of SPSS program (SPSS package program, version 9.0, SPSS Inc. USA). Different groups were statistically defined by Duncan's multiple range tests. The obtained results were considered significant at $\mathrm{p}<0.05$. 


\section{RESULTS AND DISCUSSION}

Table 1 presents chemical composition properties of the all samples. The chemical composition of the samples was determined as: the crude protein, the ash and salt contents of the dried Tarhana were found to be $10,62 \%$ and $14,0 \%, 1,25 \%$ and $2,65,0,65 \%$ and $0,82 \%$, respectively. Also, it was determined to moisture $6,85 \%$ and $7,30 \%, \mathrm{pH} \mathrm{3,22-3,82.} \mathrm{Dayisoylu} \mathrm{et} \mathrm{al.} \mathrm{[21]} \mathrm{reported} \mathrm{that} \mathrm{the} \mathrm{same}$ levels of moisture was determined in the samples to Maras tarhana. The moisture contents of Tarhana samples were determined as 7,34\% [9] and 9,35\% [22].

Protein content of Tarhana chips determined $10,62 \%$ and $14,0 \%$ respectively as shown in Table 1 . It was reported that protein content of corn tortilla chips was $9,1 \mathrm{~g} / 100 \mathrm{~g}$ indicating that Tarhana chips had higher protein than corn tortilla chips $(12,0 \mathrm{~g} / 100 \mathrm{~g})$ [23]. These results are similar to those reported by [6,7-24]. The moisture and protein contents determined as 8,6 and 11,5\%, 10,4 and 13,6\%, respectively. The product, tarhana chips, offers and advantageous possibilities as an increased nutritive value or high-protein enriched food as reported by [24].

Table 1 presents the antioxidant capacity of tarhana samples. DPPH and ABTS* values of tarhana samples extracts were significantly different in control and tarhana samples fermented with Kefir. These results indicated that the control tarhana chips samples $(0,47 \pm 0,51 \mu \mathrm{mol} / \mathrm{g}$ TE) had significantly $(P<0.05)$ lower antioxidant capacity than the fermented with kefir $(0,67 \pm 0,02 \mu \mathrm{mol} / \mathrm{g} \mathrm{TE})$ samples.

Table 1. Chemical composition and antioxidant capacity of Tarhana chips, yogurt and kefir samples

\begin{tabular}{|c|c|c|c|}
\hline Chemical Properties & KT & YT & $P s$ \\
\hline Moisture (\%) & $7,30 \pm 0,01$ & $6,85 \pm 0,00$ & NS \\
\hline $\operatorname{Ash}(\%)$ & $1,25 \pm 0,02$ & $2,65 \pm 0,03$ & $*$ \\
\hline Crude Protein $(\%)$ & $14,00 \pm 0,01$ & $10,62 \pm 0,01$ & $*$ \\
\hline $\mathrm{pH}$ & $3,69 \pm 0,02$ & $3,94 \pm 0,03$ & NS \\
\hline$* \mathrm{~L}$ & $78,12 \pm 0,03$ & $80,11 \pm 0,01$ & NS \\
\hline$* \mathrm{a}$ & $4,52 \pm 0,11$ & $4,59 \pm 0,08$ & NS \\
\hline$* \mathrm{~b}$ & $28,01 \pm 0,01$ & $27,85 \pm 0,01$ & NS \\
\hline ABTS $(\mu \mathrm{mol} \mathrm{TE} / \mathrm{g})$ & $0,83 \pm 0,28$ & $0,71 \pm 0,32$ & $*$ \\
\hline DPPH $(\mu \mathrm{mol} \mathrm{TE} / \mathrm{g})$ & $0,67 \pm 0,02$ & $0,47 \pm 0,51$ & $* *$ \\
\hline Chemical Properties & K & $\mathrm{Y}$ & Ps \\
\hline Crude Protein $(\%)$ & $4,20 \pm 0,11$ & $3,80 \pm 0,07$ & NS \\
\hline $\mathrm{pH}$ & $4,60 \pm 0,02$ & $4,64 \pm 0,03$ & NS \\
\hline$* \mathrm{~L}$ & $98,12 \pm 0,23$ & $97,40 \pm 0,01$ & NS \\
\hline$* \mathrm{a}$ & $-1,78 \pm 0,00$ & $-1,89 \pm 0,01$ & NS \\
\hline$* \mathrm{~b}$ & $8,68 \pm 0,05$ & $7,51 \pm 0,01$ & $*$ \\
\hline ABTS $(\mu \mathrm{mol} \mathrm{TE} / \mathrm{g})$ & $1,61 \pm 0,08$ & $1,56 \pm 0,01$ & $*$ \\
\hline DPPH $(\mu \mathrm{mol} \mathrm{TE} / \mathrm{g})$ & $6,99 \pm 0,61$ & $6,17 \pm 0,06$ & $*$ \\
\hline
\end{tabular}

The ABTS values of extracts were significantly different in YT sample and KT samples fermented with kefir. The previous study show that DPPH radical scavenger activity were $0,8390 \mu \mathrm{mol} / \mathrm{TE} \mathrm{g}$ and $1,5182 \mu \mathrm{mol} / \mathrm{TE} \mathrm{g}$ at some tarhana samples of home type produced in Maras and Antep region [32].

$\mathrm{L}^{*}$ values in tarhana samples determined 78,12 and 80,11 $(P<0.05)$. Redness $(\mathrm{a} *)$ values of fermented tarhana chips kefir and yoghurt fermented $\mu$ samples were 4,52 $\pm 0,11$ and 4,59 $\pm 0,08$, respectively, while the values of yellowness $(b *)$ were determined as $28,01 \pm 0,01$ and $27,85 \pm 0,01$, respectively. No significant differences were observed in $\mathrm{a}^{*}$ or $\mathrm{b}^{*}$ values between the samples, fermented kefir or control $(P>0.05)$. The same results were observed by [25]. In other study, It was investigated some 
physicochemical properties of 40 different house type tarhanas chips in Kahramanmaras. According to the results of color values between $\mathrm{L} * 55.25-81.41$ and between $\mathrm{a} * 2,26-13,9$ and between $\mathrm{b} * 21,73$ 32,09 [31]. In another study, results related to color characteristics $L^{*} 78,6, a^{*} 0,0$ and $b^{*} 15,5$ [32].

The basic microbiological data for tarhana chips samples, yogurt and kefir are shown in Table 2. None of the samples contained coliform group bacteria and mould. In the tarhana chips, count for Lactobacillus spp. and total mesophilic aerobic bacteria determined 8,47 -8,94 log cfu/g and 7,43-7,95 $\log \mathrm{cfu} / \mathrm{g}$, respectively. The total amount of yeast was determined as $6,89 \mathrm{log} \mathrm{cfu} / \mathrm{g}$ in the tarhana chips samples fermented with kefir, whereas no yeast was detected in control samples fermented with yogurt.

The lactic acid bacteria and yeasts included in kefir and yogurt-like dairy products are responsible for the taste of tarhana by playing an important role in the production of lactic acid, ethanol, carbon dioxide and some organic compounds [6]. Due to lower levels of $\mathrm{pH}(\sim 4.30)$ and moisture content $(6,00$ $8,85 \%)$, tarhana is an unfavorable environment for pathogens and spoilage microorganisms. Kefir grain has a very complex microbial flora. Grain flora passes through the product during kefir production and creates unique flavor and aroma of kefir, affecting the product texture. Kefir is a product made up of lactic acid and yeast fermentation, which is separated from other fermented dairy products.

Table 2. Microbiological Properties of Tarhana chips samples and yogurt/kefir

\begin{tabular}{|c|c|c|c|c|c|}
\hline Microbiological Properties (log cfu/g) & KT & $\mathrm{YT}$ & $\mathrm{K}$ & $\mathrm{Y}$ & Ps \\
\hline Total coliform & ND & ND & ND & ND & NS \\
\hline Total mesophilic aerobic bacteria & $7,95 \pm 0,31$ & $7,43 \pm 0,01$ & $7,41 \pm 0,01$ & $7,81 \pm 0,01$ & NS \\
\hline Lactobacillus spp. & $8,94 \pm 0,11$ & $8,47 \pm 0,63$ & $8,31 \pm 0,13$ & $6,90 \pm 0,06$ & $* *$ \\
\hline Total Yeast & $6,89 \pm 0,24$ & ND & $5,56 \pm 0,08$ & ND & $* * *$ \\
\hline Total Mould & ND & ND & ND & ND & NS \\
\hline
\end{tabular}

*P<0.05; **P<0.01; *** $\mathrm{P}<0.001$; NS: No signifigant $\mathrm{s}$ : sample K: kefir; YT: control, KT: tarhana chips fermented with kefir

Some studies on kefir have reported that contents of yeast from 5-8 log cfu/g [26,27]. Seydim [28] found kefir yeast content to be $6,56 \mathrm{log} \mathrm{cfu} / \mathrm{ml}$. Güzel-Seydim et al. [29] found that the number of lactococci, lactobacilli and yeasts in Turkish kefir grain was 9,05;8.87 and 6,55 log cfu / ml, respectively. The results showed that kefir addition in tarhana formulation exhibited was significant for yeast presence $(\mathrm{P}<0.05)$ (Table 2).

\section{CONCLUSION}

This study indicated that the addition of yoghurt and kefir significantly affects the microbiological properties and antioxidant levels of tarhana chips.

These results indicated that the control samples had significantly $(P<0.05)$ lower antioxidant capacity than the fermented with kefir samples. For this reason, the use of kefir instead of yoghurt in the production of tarhana chips will increase the antioxidant activity and will make a significant contribution to the nutritive and functional value of the tarhana chips in human nutrition. The results confirmed that kefir is a suitable ingredient for tarhana chips production. Kefir had some improving effects on nutritional and functional properties of tarhana.

\section{REFERENCES}

[1] Blandino A, Al-Aseeri ME, Pandiella SS, Cantero D, Webb C. Cereal Based Fermented Foods and Beverages. Food Res Int 2003; 36: 527-543.

[2] Isık F, Çelik I, Yılmaz Y. Effect of Cornelian Cherry Use on Physical and Chemical Properties of Tarhana. Akademik Gida 2014; 12:34-40. 
[3] Karakaya S, Kavas A. Antimutagenic activities of some foods. J Sci of Food \& Agri 1999; 79: 237-242.

[4] Ibanoglu S, Ibanoglu E, Ainsworth P. Effect of different ingredients on the fermentation activity in tarhana. Food Chem 1999; 64: 103-106.

[5] Ibanoglu S, Ibanoglu E. Rheological properties of cooked Tarhana, a cerealbased soup. Food Res Int. 1999; 32: 29-33.

[6] Erbaş M, Certel M, Uslu MK. Microbiological and chemical properties of tarhana during fermentation and storage as wet-sensorial properties of tarhana soup. LWT-Food Science \&Technology 2005; 38: 409-416.

[8] Dayısoylu O. Tarhana as a traditional Turkish fermented cereal food: its recipe, related products. Frontiers Microbiology 2000; 6: 1-12.

[7] Ibanoglu S Ainsworth P, Wilson G, Hayes GD. The effect of fermentation conditions on the nutrients and acceptability of tarhana. Food Chem 19995; 53: 143-147.

[9] Yörükoglu T, Dayısoylu KS. Yöresel Maraş Tarhanasının Fonksiyonel ve Kimyasal Bazı Özellikleri. Atatürk Universty J Agri Faculty 2016; 47: 53-63.

[10] Coşkun F. Tarhananın tarihi ve Türkiye'de tarhana çeşitleri. Gıda Teknolojileri Elektronik Dergisi 2014; 9: 69-79.

[11] Motaghi M, Mazaheri M, Moazami N, Farkhondeh A, Fooladi FH. Goltapeh, E.M. Short Communication: Kefir production in Iran. World Journal of Microbiology and Biotechnology 1997; 13: 579-581. [12] Güzel-Seydim ZB, Seydim AC, Greene AK, Bodine AB. J Food Composition \& Analysis 2000; 13: 35-43.

[13] Magalhães KT, Pereira GVM, Dias DR, Schwan RF. Microbial communities and chemical changes during fermentation of sugary Brazilian kefir. World J Micro \& Biotec 2010; 26: 12411250 .

[14] Garofalo C, Osimani A, Milanovi CV, Aquilanti L, De Filippis F, Stellato G, Di Mauro S, Turchetti B, Buzzini P, Ercolini D, Clementi F. Bacteria and yeast microbiota in milk kefir grains from different Italian regions. Food Micro 2015; 49, 123-133.

[15] Magalhães Karina T, Dragone Giuliano V de Melo Pereira, Gilberto Oliveira José M. Oliveira Domingues Lucília Teixeira José A, Almeida e Silva João B, Schwan Rosane F. Food Chem 2011; 126: 249-253.

[16] Prado MR, Bland ML, Vandenberghe LPS, Rodrigues CC, Guillermo R, Thomaz-Soccol VT, Soccol CR. Milk kefir: composition, microbial cultures, biological activities and production and vomposition. Frontiers Micro 2015; 6: 1177-1190.

[17] AOAC. Official methods of analysis, (15th ed.), 1990; Washington, DC: Association of Official Analytical Chemists.

[18] Anonymous. Approved Method of the American Association of Cereal Chemists.1990; 8th ed. St. Paul, Minnesota: AACC. U.S.A. 
[19] Xu C, Zhang Y, Cao L, Lu J. Phenolic compounds and antioxidant properties of different grape cultivars grown in China. Food Chem 2010; 119: 1557-1565.

[20] Sahingil D, Hayaloglu AA, Simsek O, Ozer B. Changes in volatile composition, proteolysis and textural and sensory properties of white-brined cheese: effects of ripening temperature and adjunct culture. Dairy Sci Tech 2014; 94: 603-623.

[21] Dayısoylu KS, Gezginç Y, Duman AD, Didin M. Geleneksel Kahramanmaraş Tarhanasının Kimi Özellikleri ve Beslenmedeki Fonksiyonel Önemi. 3. Gıda Mühendisliği Kongresi 2003; 2-4 Ekim, Ankara.

[22] Tamer CE, Kumral A, Asan M, Sahin I. I. Chemical Compositions of Traditional Tarhana Having Different Formulations. J Food Processing \& Preservation 2007; 31: 116-126.

[23] Rendón-Villalobos JR, Bello-Pérez LAE, Agama-Acevedo E, IslasHernández JJ, Osorio-Díaz P, Tovar J. Composition and characteristics of oil extracted from flaxseed-added corn tortilla. Food Chem 2009; 117: 83-87.

[24] Lazos ES, Aggelousis G, Bratakos M. The fermentation of Trahanas: a milk- wheat flour combination. Plant Foods for Human Nutrition 1993; 44: 45-62.

[25] Ozçam M, Obuz E, Tosun H. Aflatoxin M1 in Tarhana chips. Food Additives \& Contaminants 2014; $7: 182-185$.

[26] Magra TI, Antoniou KD, Psomas EI. Effect of milk fat, kefir grain inoculum and storage time on the flow properties and microbiological characteristics of kefir. Journal of Texture Studies 2012;43: 299-308

[27] Sarkar S. Potential of kefir as a dietetic beverage-a review. British Food Journal 2007; 109: 280290.

[28] Seydim ZB. Studies on Fermentative, Microbiological and Biochemical Properties of Kefir and Kefir Grains. Ph. D, The Graduate School of Clemson University, Clemson, US A, 2002.

[29] Güzel-Seydim ZB, Wyffels J, Seydim AC. Greene AK. Turkish kefir and kefir grains: microbial enumeration and electron microscobic observation. J Int Dairy Technology 2005; 58: 25-29.

[30] Anonymous. Tarhana Standard1 2004; TS 2282 Turkish Standards Institution, Ankara

[31] Ozçam M, Obuz E. Kahramanmaraş Cips Tarhanasının Kimyasal ve Tekstürel Özellikleri, III. Geleneksel Gıdalar Sempozyumu 2012; (s. 501-502). Konya, Türkiye.

[32] Esimek H. Tarhananın besinsel lif içeriği ve antioksidatif özelliklerinin belirlenmesi. İnönü Üniversitesi Fen Bilimleri Enstitüsü 2010; 1-68 ss. 